\title{
PENGARUH KEPEMIMPINAN DAN KOMUNIKASI INTERN TERHADAP EFEKTIVITAS KERJA PEGAWAI DI FITK UIN RADEN FATAH PALEMBANG
}

\author{
Rusmaini \\ Universitas Islam Negeri Raden Fatah Palembang \\ Email: rusmaini_uin@radenfatah.ac.id
}

\begin{abstract}
Work effectiveness is the degree of achievement of an organization's goals based on the activities carried out. Work effectiveness is influenced by various factors including leadership, internal communication. The research objectives are: (1) to determine whether there is the influence of leadership and internal communication on work effectiveness (2) to find out how much influence leadership and internal communication have on employee work effectiveness both simultaneously and partially. The population of this study was employees of the Tarbiyah and Teacher Training Faculty of UIN Raden Fatah Palembang; it is 90 people. There are three variables studied in this study, namely: (1) leadership (2) internal communication (3) work effectiveness. Data collection methods used are questionnaires and documentation. The data analysis method used is the descriptive analysis of percentages and multiple linear regression analysis using SPSS for Windows Release 16. Based on the descriptive analysis, the percentage of leadership is $84.24 \%$ (very good category), the level of internal communication is $86 \%$ (very good category), while the level of work effectiveness is $78.78 \%$ (good category). Based on the calculation of multiple linear regression analysis also obtained $F$ calculate of 17,234 with a significance of 0,000. Because the price of significance obtained is less than 0.05, the regression model obtained is significant. This means that the working hypothesis ( $\mathrm{Ha}$ ) is accepted, that is, there is the influence of leadership and internal communication on work effectiveness. The magnitude of the effect is simultaneously $28.4 \%$ while partially is $16 \%$ for leadership variables and $5.29 \%$ for internal communication. Based on the results of research, leadership and internal communication have a positive influence on work effectiveness. Leadership has a greater influence than internal communication.
\end{abstract}

Keywords. Leadership, Internal Communication, Work Effectiveness

Abstrak. Efektivitas kerja merupakan derajat pencapaian tujuan suatu organisasi berdasarkan aktivitas-aktivitas yang dilakukan. Efektivitas kerja dipengaruhi oleh berbagai faktor antara lain kepemimpinan dan komunikasi intern. Tujuan penelitian adalah: (1) untuk mengetahui ada tidaknya pengaruh kepemimpinan dan komunikasi intern terhadap efektivitas kerja (2) untuk mengetahui seberapa besar pengaruh kepemimpinan dan komunikasi intern terhadap efektivitas kerja pegawai baik secara simultan maupun parsial. Populasi penelitian ini adalah pegawai Fakultas Ilmu Tarbiyah dan Keguruan UIN Raden Fatah Palembang. Sehingga jumlah populasi adalah 90 orang. Ada tiga variabel yang dikaji dalam penelitian ini yaitu: (1) kepemimpinan (2) komunikasi intern (3) efektivitas kerja. Metode pengumpulan data yang digunakan adalah angket dan dokumentasi. Metode analisis data yang digunakan adalah analisis deskriptif persentase dan analisis regresi linier ganda dengan menggunakan SPSS for windows release 16. Berdasarkan analisis deskriptif persentase diperoleh besarnya kepemimpinan adalah sebesar 84,24\% dan termasuk kategori sangat baik, tingkat komunikasi intern sebesar $86 \%$ termasuk kategori sangat baik, sedangkan tingkat efektivitas kerja sebesar 78,78\% termasuk kategori baik. Berdasarkan perhitungan analisis regresi linier ganda juga diperoleh Fhitung sebesar 17,234 dengan signifikansi 
0,000. Karena harga signifikansi yang diperoleh tersebut kurang dari 0,05, maka model regresi tersebut yang diperoleh signifikan. Hal ini berarti bahwa hipotesis kerja (Ha) diterima, yaitu ada pengaruh kepemimpinan dan komunikasi intern terhadap efektivitas kerja. Besarnya pengaruh tersebut secara simultan $28,4 \%$ sedangkan secara parsial adalah 16\% untuk variabel kepemimpinan dan 5,29\% untuk komunikasi intern. Berdasarkan hasil penelitian, kepemimpinan dan komunikasi intern memberikan pengaruh yang positif terhadap efektivitas kerja. Kepemimpinan mempunyai pengaruh yang lebih besar dari pada komunikasi intern.

Kata Kunci. Kepemimpinan, Komunikasi Intern, Efektivitas Kerja

Copyright (C JMPI: Jurnal Manajemen Pendidikan Islam. All Right Reserved.

This is an open access article under the CC BY-NC-ND license

(http://creativecommons.org/licenses/by-nc-nd/4.0/).

\section{A. PENDAHULUAN}

Efektivitas dalam pelaksanaan tugas dan tanggungjawab akan sangat berpengaruh dalam pencapaian tujuan. Efektivitas merupakan suatu dasar pembentukan dan penyelenggaraan organisasi kampus. Oleh karena itu, eksistensi dan pertumbuhan organisasi kampus khususnya Fakultas Ilmu Tarbiyah dan Keguruan UIN Raden Fatah Palembang akan terwujud apabila organisasi tersebut dapat mencapai efektivitas kerja para personel yang ada di dalamnya. Untuk mewujudkan efektivitas kerja yang positif tentunya bukan merupakan usaha yang mudah, karena dipengaruhi beberapa faktor diantaranya lingkungan kerja, tata ruang kantor, suasana kerja, gaya kepemimpinan dan komunikasi baik intern maupun ekstern dan lain sebagainya. Salah satu kekuatan efektivitas dalam pengelolaan organisasi yang berperan bertanggung jawab menghadapi perubahan adalah kepemimpinan. Dimana kepemimpinan adalah perilaku pimpinan sesuai dengan bagian kerja mereka. Kepemimpinan yang mampu memprakarsai pemikiran baru dalam proses interaksi di lingkungan kerja dengan melakukan tujuan, prosedur, input, proses dan output sesuai dengan tuntunan perkembangan.

Dalam suatu organisasi atau instansi, kepemimpinan berkaitan dengan pengarahan kepada pegawai untuk melakukan pekerjaan. Ini menjadi bagian penting dalam memahami perilaku kerja. Beberapa penelitian telah memperlihatkan bahwa tidak ada "satu cara terbaik untuk memimpin bawahan". Ini tergantung pada pemimpinnya, bawahan, dan situasi yang ada. Pemimpin yang baik akan mendapatkan hasil pekerjaan lebih banyak dari bawahannya dengan sikap sebagai pemimpin yang baik. Gaya kepemimpinan yang diterapkan dalam suatu organisasi dapat membantu menciptakan efektivitas kerja yang positif bagi pegawai. Gaya kepemimpinan yang sesuai dengan situasi dan kondisi organisasi akan menjadikan pegawai lebih semangat dalam menjalankan tugas dan kewajibannya dan mempunyai harapan terpenuhinya kebutuhan.

Menurut Terry dan Rue (Usman, 2013:304), kepemimpinan adalah kemampuan memengaruhi orang lain untuk bekerja sama secara sadar dalam hubungan tugas yang diinginkan. Sementara praktisi biasanya menerapkan pemimpin adalah orang yang menerapkan prinsip dan teknik yang memastikan motivasi, disiplin dan produktivitas jika bekerja sama dengan orang lain, tugas dan situasi agar mencapai tujuan organisasi. Suyuti (2001:7) memaknai kepemimpinan dengan proses mengarahkan, membimbing 
dan mempengaruhi pikiran, perasaan, tindakan dan tingkah laku orang lain. Sedangkan menurut Asmara (1985:17), memaknai kepemimpinan sebagai tingkah laku untuk mempengaruhi orang lain. Menurut (Kartono, 2008:36) persyaratan kepemimpinan itu harus selalu dikaitkan dengan tiga hal penting, yaitu: Kekuasaan ialah kekuatan, otoritas dan legalitas yang memberikan wewenang kepada pemimpin guna mempengaruhi dan menggerakkan bawahan untuk berbuat sesuatu. Kewibawaan ialah kelebihan, keunggulan, keutamaan, sehingga orang mampu "Mbawani" atau mengatur orang lain, sehingga orang tersebut patuh pada pemimpin, dan bersedia melakukan perbuatanperbuatan tertentu. Kemampuan ialah segala daya, kesanggupan, kekuatan dan kecakapan atau keterampilan teknis maupun sosial, yang dianggap melebihi dari kemampuan anggota biasa. Selanjutnya (Kartono, 2008:34) meberikan indikator dari pemimpin sebagai berikut : a) kemampuan mengambil keputusan, b) kemampuan memotivasi, c) kemampuan komunikasi, d) kemampuan mengendalikan bawahan, e) tanggung jawab, dan f) kemampuan mengendalikan emosional.

Untuk memilih gaya kepemimpinan yang akan digunakan, perlu dipertimbangkan berbagai faktor yang mempengaruhinya. Menurut Haris (dalam Kartono, 2008:173), meskipun banyak faktor yang perlu dipertimbangkan, membaginya ke dalam 4 (empat) faktor yaitu : a) faktor dalam organisasi, b) faktor pimpinan manajer, c) faktor bawahan, d) faktor situasi penugasan. Teori kepemimpinan dengan pendekatan situasional (kontingensi), salah satnya yaitu teori dauir hidup dari Hersey dan Blanchard, mereka mengungkapkan empat gaya kepemimpinan yaitu: Pertama Telling (memberitahukan atau mengarahkan). Kedua Selling (mempromosikan). Ketiga Delegating (mendelegasikan).

Sedangkan komunikasi dalam sebuah lemabaga sanagat berkaitan dengan hubungan pemimpin dan bawahannya. Seorang pemimpin dalam instansi harus dapat melaksanakan kepemimpinannya secara efektif. Untuk itu, harus mampu melakukan komunikasi secara efektif. Seorang manajer dikatakan berkomunikasi efektif bila ia mampu membuat karyawan melakukan kegiatan tertentu dengan kesadaran, kegairahan dan kegembiraan. Tanpa komunikasi yang baik, mustahil akan tercipta suasana kerja yang kondusif. Hubungan antar sesama karyawan jadi terganggu dan itu dapat membuat karyawan merasa tidak nyaman dan tidak termotivasi dalam meningkatkan kinerjanya.

Menurut (Effendy, 2003:9) istilah komunikasi (communication) berasal dari kata latin communication, dan bersumber dari kata communis yang berarti sama. Sama disini maksudnya adalah sama makna. Carl I. Hovland (dalam Arifin, 1994:14) merumuskan komunikasi dengan proses mengoper stimuli untuk mengubah tingkah laku individu yang lain. James A. F. Stoner (dalam Widjaja, 2000:13) bahwa komunikasi adalah proses dimana seseorang berusaha memberikan pengertian dengan cara pemindahan pesan. Sedangkan Harold D. Lasswell (dalam Cangara, 2005:19) memberikan kunci kata siapa, berkata apa, saluran apa, kepada siapa dan bagaimana efeknya. Lebih singkat John R. Schemerhom (dalam Widjaja, 2000:13-14) memaknai dengan mengirim dan menerima simbol-simbol bagi kepentingan mereka.

Besarnya efek komunikasi terhadap pencapaian kerja instansi sesuai dengan fungsi komunikasi yaitu untuk meningkatkan hubungan insani (human relation), menghindari dan mengatasi konflik-konflik pribadi, mengurangi ketidakpastian sesuatu, serta berbagi pengetahuan dan pengalaman dengan orang lain. Komunikasi dan 
kepercayaan dari pemimpin yang di rasakan oleh bawahan akan mengakibatkan arahan, bimbingan dan bantuan pemimpin yang di berikan kepada bawahan akan menyatu dan memudahkan bawahan untuk menangkap makna dari upaya yang dilakukan dan komunikasi instansi akan efektif untuk menyadarkan dan melatih pegawai untuk lebih mengamalkan nilai moral dasar dalam melaksanakan pekerjaan mereka dan membentuk pribadi yang mandiri, percaya diri, dan mempunyai rasa tanggung jawab yang tinggi dari masing-masing pegawai.

Sebuah komunikasi dalam organisasi yang trubel akan berdampak negatif pada penyampaian pesan dan juga akan mempengaruhi arus informasi yang ingin disampaikan. Sebagaimana pengertian komunikasi adalah suatu proses pertukaran pesan verbal maupun nonverbal antara si pengirim pesan dengan si penerima pesan untuk mengubah tingkah laku (Muhammad, 2001:5). Sedangkan komunikasi intern adalah proses penyampaian pesan-pesan yang berlangsung antar anggota organisasi, dapat berlangsung antara pimpinan dengan bawahan, pimpinan dengan pimpinan, maupun bawahan dengan bawahan (Muhyadi, 1989:164). Komunikasi intern yang terbina baik akan memberikan kemudahan dan keringanan dalam melaksanakan pekerjaan yang menjadi tugas bersama.

Dengan kata lain penerima pesan dalam komunikasi intern adalah orang orang dalam organisasi (Muhammad, 2001: 97). Adapun prinsip komunikasi intern yang harus dimiliki oleh seorang pimpinan organisasi selain tersebut di atas adalah sebagai berikut: a) pimpinan harus mengadakan persiapan secara seksama sebelum berkomunikasi, b) pimpinan harus membangkitkan perhatian komunikator sebelum komunikasi dimulai, c) memelihara kontak pribadi selama berkomunikasi, d) tunjukan diri sebagai komunikator yang baik, e) berbicara secara menyakinkan, f) bersikap empatik dan simpatik, g) bertindak sebagai pembimbing bukan pendorong, dan h) mengemukakan pesan komunikasi yang menyangkut kepentingan komunikan, bukan kepentingan komunikator semata (Effendy, 2001: 126).

Komunikasi intern akan lebih efektif, jika berbagai faktor yang mendukung keberhasilan dapat digunakan secara bersama-sama. Faktor-faktor tersebut diantaranya: berusaha memperoleh umpan balik, menggunakan bahasa yang benar dengan diikuti gerakan badan untuk memperjelas isi pesan, dan bila perlu dilakukan pengulangan dalam hal penyampaian, menempatkan diri baik sebagai penyampai maupun penerima. Adanya komunikasi intern pada sebuah instansi, maka koordinasi dan kerjasama dalam melaksanakan pekerjaan bisa berjalan dengan baik. Dengan komunikasi yang baik, maka tidak menimbulkan keragu-raguan dan kesalah-pahaman bawahan sehingga informasi dan petunjuk yang mereka peroleh jelas dan akhirnya akan mempengaruhi efektivitas kerja mereka.

Arah dan jenis informasi yang ingin disampaikan akan menentukan dimensi aliran komunikasi. Aliran dan jenis komunikasi sebagai berikut: Pertam komunikasi ke bawah, yang dimulai dari manajer puncak kemudian mengalir ke bawah melalui tingkatan-tingkatan manajemen sampai ke pegawai lini dan personalia paling bawah (Handoko, 1995: 280). Kedua komunikasi ke atas, yang digunakan untuk mensuplai informasi kepada tingkatan manajemen atas, tentang apa yang terjadi pada tingkatan bawah. Tujuan dari komunikasi ini adalah untuk memberikan saran, memberikan balikan, dan mengajukan pertanyaan, sehingga komunikasi ini mempunyai efek pada penyempurnaan moral dan sikap pegawai, tipe pesan adalah integrasi dan pembaharuan 
(Handoko, 1995:116). Ketiga komunikasi horizontal, yang terjadi antara bagian-bagian yang memiliki posisi sejajar / sederajat dalam suatu organisasi (Purwanto, 2006:42).

Efektivitas pada dasarnya berasal dari kata "efek" dan digunakan istilah ini sebagai hubungan sebab akibat (Pasolong, 2007:4). Efektivitas menurut arti harfiahnya adalah suatu efek atau akibat yang dikehendaki dalam suatu perbuatan. Sedangkan Handayaningrat (1996:16) memaknai efektivitas sebagai pengukur tercapainya tujuan yang telah ditentukan. Merujuk Susanto (2008:41) efektivitas dapat dimaknai sebagai informasi lengkap yang dibutuhkan dalam mendukung lembaga, disajikan dalam waktu dan format yang tepat dengan keadaan saat ini. Sedangkan Amsyah (2008:131), efektifitas merupakan kegiatan dengan fakta yang berasal dari hubungan dan transaksi internal dan eksternal maupun berasal dari hubungan antar unit dan di dalam unit itu sendiri dan menjadi data. Menurut (Robins, 1996:24), faktor-faktor yang mendorong peningkatan efektivitas kerja pegawai, adalah: a) sikap (disiplin), b) kepentingan atau minat, c) motif, d) pengalaman masa lalu, dan e) penerapan (dispektasi). Selanjutnya menurut (Robins, 1996:225), terdapat empat faktor yang dapat mendukung atau mendorong tingkat efektifitas kerja pegawai, yaitu: a) kendali (kontrol pengawasan), b) motivasi, c) pengungkapan emosional, dan d) informasi.

Efektivitas adalah pemanfaatan sumber daya, sarana dan prasarana dalam jumlah tertentu yang secara sadar ditetapkan sebelumnya untuk menghasilkan sejumlah barang atas jasa kegiatan yang dijalankan (Siagian, 2007:24). Sejalan dengan itu, Etzioni (dalam Muhyadi, 1989:227) memaknai efektivitas sebagai kemampuan mencari sumber dan memanfaatkannya secara efisien dalam mencapai tujuan tertentu. Dimana efektivitas menunjukkan taraf tercapainya suatu tujuan. Sedangkan kerja diartikan sebagai kegiatan untuk melakukan sesuatu yang dilakukan atau diperbuat dan sesuatu yang dilakukan untuk mencari nafkah, mata pencaharian". Kerja dipandang sebagai upaya untuk mewujudkan kesejahteraan umum, terutama bagi orang-orang terdekat (keluarga) dan masyarakat, untuk mempertahankan dan mengembangkan kehidupan yang harus dipertangung-jawabkan kepada Tuhan (Mulyaningtyas, 2006:125). Sedangkan menurut (Sutarto, 1991:95), efektivitas kerja adalah suatu keadaan dimana aktivitas-aktivitas jasmaniah dan rohaniah yang dilakukan oleh manusia untuk mencapai hasil sesuai dengan yang dikehendaki.

Ada empat faktor menurut (Steers, 1985:209-211) yang mempengaruhi efektivitas kerja, yaitu: a) Karakteristik Organisasi. Dilihat dari struktur dan teknologi yang dapat digunakan didalamnya. Efektivitas sebuah organisasi dipengaruhi oleh tingkat kompleksitas dan formalitas struktur serta sistem kewenangan dalam pengambilan keputusan. Teknologi yang digunakan berkaitan erat dengan stuktur sehingga mempengaruhi efektivitas sebuah organisasi. b) Karakteristik lingkungan. Keberhasilan suatu organisasi dalam mencapai tujuan, dipengaruhi oleh kemampuan dalam berinteraksi dengan lingkungannya yang mencakup tingkat keterpaduan keadaan lingkungan, ketepatan persepsi atas keadaan lingkungan, dan tingkat rasionalitas organisasi. Ketiga faktor ini mempengaruhi ketepatan tanggapan organisasi terhadap perubahan lingkungan. c) Karakteristik Pekerja. Faktor manusia merupakan faktor yang paling besar pengaruhnya terhadap efektivitas sebuah organisasi. Tingkah laku manusia merupakan dukungan yang sangat berarti, tetapi dapat pula merupakan hambatan yang dapat menggagalkan efektivitas. d) Karakteristik Kebijaksanaan dan Praktek Manajemen. Kebijaksanaan dan praktek manajemen dapat mempengaruhi pencapaian 
tujuan. Dalam hal ini mencakup kebijaksanaan dan praktek pimpinan dalam tanggung jawabnya terhadap para pekerja dan organisasinya (Steers, 1985:209-211).

Cara pengukuran efektivitas menurut Steers san Gibson menggunakan tiga unsur yakni : a) Kemampuan menyesuaikan diri. Kemampuan kerja manusia terbatas secara fisik, waktu, tempat dan pendidikan serta faktor lain yang membatasi kegiatan manusia. Adanya keterbatasan ini, menyebabkan manusia tidak dapat mencapai semua pemenuhan kebutuhannya tanpa melalui kerjasama dengan orang lain. Kemampuan menyesuaikan diri sangat penting, karena hal ini merupakan tujuan organisasi. Hal ini diperkuat dengan pendapat yang menyatakan bahwa kunci keberhasilan organisasi atau gagal kerjasama bagi pencapaian tujuan (Steers, 1985:134-135). b) Kepuasan kerja. Kepuasan kerja adalah tingkat kesenangan yang dirasakan seseorang atas peran atau pekerjaannya dalam organisasi. Tingkat rasa puas individu bahwa mereka mendapat penghargaan yang setimpal dari macam-macam aspek situasi pekerjaan dan organisasi tempat mereka berada (Steers, 1985:48). c) Prestasi Kerja. Prestasi kerja adalah suatu penyelesaian tugas pekerjaan yang sudah dibebankan sesuai dengan target yang sudah ditentukan, bahkan ada yang melebihi target yang sudah ditentukan sebelumnya (Steers, 1985:140).

Sedangkan menurut Gibson (dalam Robbins, 2002:55) menyebutkan indikator untuk mengukur efektivitas organisasi adalah: a) Produksi (Produksi), b) Efisiensi (Efficiency), c) Kepuasan (Satisfaction). Sebagaimana menurut Handoko “kepuasan kerja adalah keadaan emosional yang menyenangkan yang mana bawahan memandang pekerjaan mereka, kepuasan kerja mencerminkan perasaan seseorang terhadap pekerjaan mereka" (Handoko, 1995:130). Ukuran kepuasan meliputi sikap pegawai, pergantian pegawai (turnover), kemangkiran (absenteeism), keterlambatan, dan keluhan. d) Adaptasi (Adaptiveness). Kemampuan adaptasi adalah sampai seberapa jauh organisasi dapat menanggapi perubahan intern dan ekstern. Kriteria ini berhubungan dengan kemampuan manajemen untuk menduga adanya perubahan dalam lingkungan maupun dalam organisasi itu sendiri. Jika organisasi tidak dapat menyesuaikan diri, maka kelangsungan hidupnya akan terancam.

Hasil penelitian (Novi \& Rachmiyati, 2016) menunjukan bahwa: 1) gaya kepemimpinan direktur berpengaruh signifikan terhadap kinerja PNS Politeknik Negeri Banjarmasin. 2) secara simultan gaya kepemimpinan direktur, komunikasi, dan motivasi kerja secara simultan berpengaruh signifikan terhadap kinerja PNS Politeknik Negeri Banjarmasin. Sedangkan hasil penelitian (Andri \& Sonang, 2013) menyimpulkan ada hubungan positif antara dengan motivasi, lingkungan kerja, dan komunikasi intern terhadap kinerja karyawan. Dimana variabel yang mempunyai pengaruh dominan terhadap kinerja karyawan adalah variabel komunikasi intern, karena nilai koefisien determinasi parsial yang paling besar. Penelitian (Dhamayanti, 2007) menunjukan bahwa komunikasi antara pimpinan dengan karyawan di Pidi Project secara keseluruhan dinilai efektif dengan skor rata-rata 71.7\%, terlihat dari segi keterbukaan (openness) yaitu dengan tumbuhnya suasana keterbukaan komunikasi antara atasan, bawahan, dan rekan kerja. Dari hasil beberapa penelitian di atas menunjukan bahwa gaya kepemimpinanan dan komunikasi intern memberikan dampak pada efektivitas kerja pegawai. 


\section{B. METODE}

Populasi dalam penelitian ini adalah seluruh pegawai Fakultas Ilmu Tarbiyah dan Keguruan UIN Raden Fatah Palembang yang tidak termasuk pegawai yang menempati posisi sebagai Dekan, Wakil Dekan I, Wakil Dekan II, Wakil Dekan III, sehingga julah populasi dalam penelitian ini adalah 40 orang pegawai. Dalam penelitian ini metode pengumpulan data yang digunakan adalah: a) metode angket (kuesioner), b) metode dokumentasi. Dilakukan uji validitas digunakan untuk mendapatkan tingkat kevalidan atau kesahihan instrumen untuk mendapatkan ketepatan antara data yang sesungguhnya terjadi pada objek dengan data yang dapat dikumpulkan peneliti. Untuk menguji reliabilitas instrumen, dapat digunakan uji reliabilitas internal yang diperoleh dengan cara menganalisis data dan suatu hasil pengetesan.

Metode analisis yang digunakan dalam penelitian ini adalah : 1) Metode Analisis Deskriptif, 2) Uji Prasyarat Hipotesis yaiitu Uji Normalitas Data dan Uji homogenitas, 3) Uji Hipotesis yaitu dilakukan Uji Simultan (Uji F) dan Uji Pasial. Dalam pelaksanaan untuk menghitung deskriptif, uji normalitas, homogenitas maupun uji simulta, (uji F) dan parsial (uji t) dilakukan dengan menggunakan uji Shapiro-Wilk pada SPSS 16.

\section{HASIL}

Gambaran dari masing-masing variabel dalam penelitian ini yaitu kepempinan (X1), komunikasi intern (X2) dan efektivitas kerja (Y) dapat dilakukan dengan analisis deskriptif persentase berikut ini:

\section{Persentase Variabel Kepemmpinan}

Gambaran tentang kepemimpinan di Fakultas Ilmu Tarbiyah dan Keguruan UIN Raden Fatah Palembang berdasarkan jawaban angket dari masing-masing responden diperoleh hasil seperti disajikan pada tabel berikut:

Tabel 1.1

Distribusi Kepemimpinan FITK UIN Raden Fatah Palembang

\begin{tabular}{clcccc}
\hline \multirow{2}{*}{ Valid } & Frequency & Percent & Valid Percent & $\begin{array}{c}\text { Cumulative } \\
\text { Percent }\end{array}$ \\
\cline { 2 - 6 } & Sangat Baik & 33 & 82,5 & 82,5 & 82,5 \\
\cline { 2 - 6 } & Baik & 7 & 17,5 & 17,5 & 100 \\
\cline { 2 - 6 } & Cukup Baik & 0 & 0 & 0 & 0 \\
\cline { 2 - 6 } & Kurang Baik & 0 & 0 & 0 & 0 \\
\cline { 2 - 6 } & Sangat Kurang & 0 & 0 & 0 & \\
\hline
\end{tabular}

Sumber: Hasil analisis dengan SPSS 16.0

Dari tabel 1.1 di atas, dapat diketahui bahwa besarnya skor rata-rata kepemimpinan mencapai 74,62, dengan persentase 74,62\% dan termasuk kategori baik. Selanjutnya pada tabel 4.2 di atas, juga menunjukkan bahwa kepemimpinan di Fakultas Ilmu Tarbiyah dan Keguruan UIN Raden Fatah Palembang menunjukan (82,5\%) termasuk kategori sangat baik, sedangkan selebihnya yaitu 17,5\% dalam kategori sbaik dan untuk kategori cukup baik, kurang baik dan sangat kurang baik adalah 0\%. Lebih jelasnya deskripsi tentang kepemimpinan di Fakultas Ilmu Tarbiyah dan Keguruan UIN Raden Fatah Palembang tersebut dapat dilihat pada gambar 1.1. berikut: 
Gambar 1.1

Bagan Distribusi Kepemimpinan

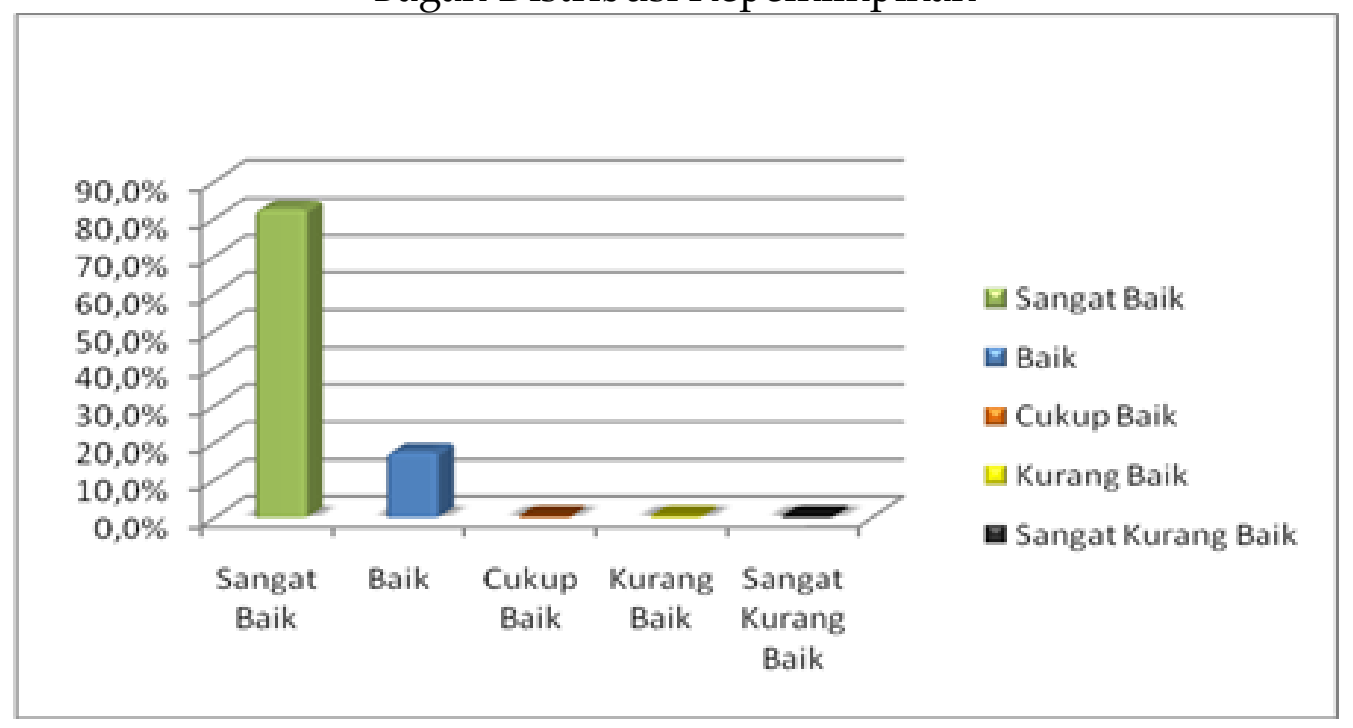

Secara lebih rinci gambaran tentang kepemimpinan di Fakultas Ilmu Tarbiyah dan Keguruan UIN Raden Fatah Palembang ditinjau dari tiap-tiap indikator yaitu Telling, Seling, Deligating dan Participating menunjukkan bahwa rata-rata skor indikator telling (memberitahukan atau mengarahkan) adalah 17,25 dengan persentase 86,25\% dan termasuk kategori baik. Rata-rata skor indikator selling (memperomosikan) pada kepemimpinan adalah 19,25 dengan persentase 77 \% dan termasuk kategori baik. Ratarata skor indikator deligating (mendelegasikan) pada kepemimpinan adalah 18,78 dengan persentase $75 \%$ dan termasuk kategori baik. Sedangkan rata-rata skor indikator participating (mengikutsertakan) pada kepemimpinan adalah 23,4 dengan persentase 78 $\%$ dan termasuk kategori baik.

\section{Persentase Variabel Komunikasi Intern}

Gambaran tentang komunikasi intern di Fakultas Ilmu Tarbiyah dan Keguruan UIN Raden Fatah Palembang berdasarkan jawaban angket dari masing-masing responden diperoleh hasil seperti disajikan pada tabel 1.2 berikut:

Tabel 1.2

Distribusi Komunikasi Intern FITK UIN RF

\begin{tabular}{llcccc}
\hline & Frequency & Percent & Valid Percent & $\begin{array}{c}\text { Cumulative } \\
\text { Percent }\end{array}$ \\
\hline Valid & Sangat Baik & 0 & 0 & 0 & 0 \\
\cline { 2 - 6 } & Baik & 32 & 80 & 80 & 80 \\
\hline Cukup Baik & 8 & 20 & 20 & 100 \\
\hline Kurang Baik & 0 & 0 & 0 & 0 \\
\hline Sangat Kurang & 0 & 0 & 0 & 0 \\
\hline Total & 40 & 100 & 100 & \\
\hline
\end{tabular}

Sumber: Hasil analisis dengan SPSS 16.0 
Dari tabel 1.2 di atas, dapat diketahui bahwa besarnya skor rata-rata komunikasi intern mencapai 74,80, dengan persentase 71,24\% dan termasuk kategori baik. Selanjutnya pada tabel 4.4 di atas, juga menunjukkan bahwa komunikasi intern di Fakultas Ilmu Tarbiyah dan Keguruan UIN Raden Fatah Palembang menunjukan $(80 \%)$ termasuk kategori baik, selebihnya 20\% dalam kategori cukup baik, sedangkan untuk kategori sangat baik, kurang baik, dan sangat kurang baik adalah $0 \%$. Lebih jelasnya deskripsi tentang komunikasi intern di Fakultas Ilmu Tarbiyah dan Keguruan UIN Raden Fatah Palembang tersebut dapat dilihat pada gambar berikut:

Gambar 1.2

Bagan Distribusi Komunikasi Intern

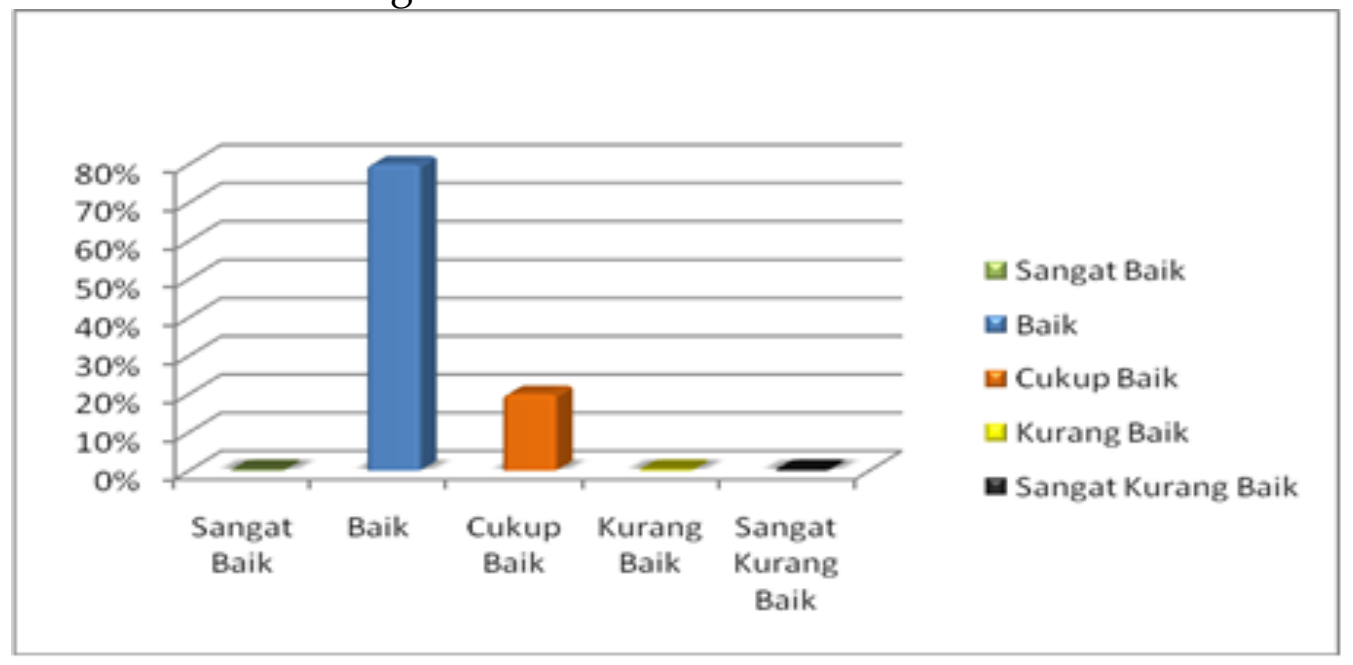

Secara lebih rinci gambaran tentang komunikasi intern di Fakultas Ilmu Tarbiyah dan Keguruan UIN Raden Fatah Palembang ditinjau dari tiap-tiap indikator yaitu komunikasi dari atas ke bawah, komunikasi dari atas ke bawah, dan komunikasi horizontal dapat disajikan sebagai berikut:

Rata-rata skor komunikasi dari atas ke bawah adalah 32,10 dengan persentase 91,71 \% dan termasuk kategori baik. Rata-rata skor komunikasi dari bawah ke atas adalah 24,80 dengan persentase 91,71 \% dan termasuk kategori baik. Sedangkan rata-rata skor komunikasi horizontal adalah 32,35 dengan persentase 80,88 \% dan termasuk kategori baik.

\section{Persentase Variabel Efektivitas Kerja Pegawai}

Perhitungan distribusi efektivitas kerja pegawai dilakukan dengan menggunakan program SPSS 16.0. Selanjutnya dilakukan pengkategorian persentase sesuai dengan kelompoknya. Gambaran tentang efektivitas kerja pegawai di Fakultas Ilmu Tarbiyah dan Keguruan UIN Raden Fatah Palembang berdasarkan jawaban angket dari masingmasing responden diperoleh hasil seperti disajikan pada tabel 1.3 berikut: 
Tabel 1.3

Distribusi Efektivitas Kerja Pegawai FITK UIN RF

\begin{tabular}{llcccc}
\hline & Frequency & Percent & Valid Percent & $\begin{array}{c}\text { Cumulative } \\
\text { Percent }\end{array}$ \\
\hline Valid & Sangat Baik & 33 & 82,5 & 82,5 & 0 \\
\cline { 2 - 6 } & Baik & 7 & 17,5 & 17,5 & 80 \\
\cline { 2 - 6 } & Cukup Baik & 0 & 0 & 0 & 100 \\
\cline { 2 - 6 } & Kurang Baik & 0 & 0 & 0 & 0 \\
\cline { 2 - 6 } & Sangat Kurang & 0 & 0 & 0 & \\
\cline { 2 - 6 } & Total & 40 & 100 & 100 &
\end{tabular}

Sumber: Hasil analisis dengan SPSS 16.0

Dari tabel 1.3 di atas, dapat diketahui bahwa besarnya skor rata-rata komunikasi intern mencapai 74,95, dengan persentase 93,69\% dan termasuk kategori baik. Selanjutnya pada tabel 4.4 di atas, juga menunjukkan bahwa komunikasi intern di Fakultas Ilmu Tarbiyah dan Keguruan UIN Raden Fatah Palembang menunjukan (82,5\%) termasuk kategori sangat baik, sedangkan selebihnya yaitu 17,5\% dalam kategori baik dan $0 \%$ dalam kategori cukup, kurang baik dan sangat kurang baik. Lebih jelasnya deskripsi tentang efektivitas kerja pegawai di Fakultas Ilmu Tarbiyah dan Keguruan UIN Raden Fatah Palembang hasil perhitungan menggunakan SPSS. 16.0 dapat dilihat pada gambar 1.3 berikut :

Gambar 1.3

Bagan Distribusi Efektivitas Kerja Pegawai

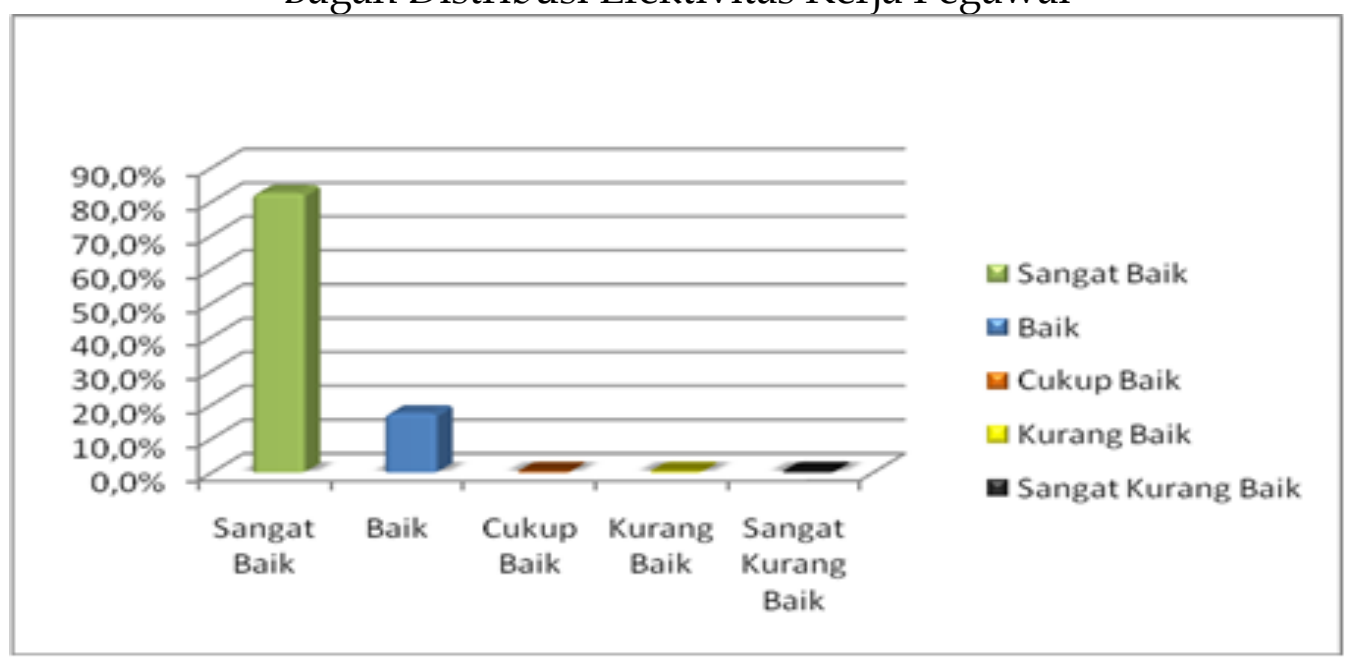

Secara komulatif persentase efektivitas kerja pegawai berada pada posisi sangat baik. Lebih rinci gambaran tentang efektivitas kerja pegawai di Fakultas Ilmu Tarbiyah dan Keguruan UIN Raden Fatah Palembang ditinjau dari tiap-tiap indikator yaitu kemampuan menyesuaikan diri, prestasi kerja pegawai, dan kepuasan kerja pegawai dimana rata-rata skor kemampuan menyesuaikan diri pegawai adalah 23,65 dengan persentase $94,6 \%$ dan termasuk kategori sangat baik. Rata-rata skor prestasi kerja pegawai adalah 28,30 dengan persentase 94,33\% dan termasuk kategori sangat baik. Sedangkan rata-rata skor kepuasan kerja pegawai adalah 23,48 dengan persentase 93,92\% dan termasuk kategori sangat baik. 
Setelah mendapatkan persentase dilakukan analisis regresi ganda berdasarkan perhitungan komputer dengan program statistik SPSS release 16.0 diperoleh hasil perhitungan yang nampak pada lampiran. Terlebih dahulu dilakukan uji normalitas yang digunakan dalam penelitian ini adalah uji One sample Kolmogrov-smirnov dengan menggunakan taraf signifikasi 0,05. Data dinyatakan berdistribusi normal jika signifikasi lebih besar dari 5\% atau 0,05. Diperoleh angka probalilitas atau Asymp. Sig. (2-tailed) variabel kepemimpinan 0,177, komunikasi 0,074, dan efektivitas kerja 0,243 sehingga dapat disimpulkan data seluruh variabel berdistribusi normal. Sedangkan hasil uji homogenitas adalah variabel kepemimpinan0,112 dan variabel komunikasi intern 0,607, karena nilai signifikan lebih dari 0,05 maka disimpulkan bahwa data hasil penelitian untuk seluruh variabel memiliki varians populasi yang homogen.

Selanjutnya hasil uji chi untuk menguji keberartian pengaruh dari masing-masing variabel bebas yaitu kepemimpinan dan (X1) dan komunikasi intern (X2) terhadap efektivitas kerja pegawai (Y). Berdasarkan hasil perhitungan menunjukkan bahwa untuk variabel kepemimpinan diperoleh nilai sig $=0,019$ dan variabel komunikasi intern diperoleh nilai sig =0,03. Karena harga signifikansi yang diperoleh kurang dari 0,05, menunjukkan bahwa nilai yang diperoleh tersebut signifikan, hal ini berarti bahwa variabel kepemimpinan dan komunikasi intern berpengaruh secara signifikan terhadap efektivitas kerja pegawai.

Hubungan antara masing-masing variabel bebas dengan variabel terikat dalam penelitian ini dapat diketahui dari harga koefisien korelasi secara parsial. Berdasarkan hasil analisis dengan menggunakan program komputasi SPSS for Windows release 16.0 diperoleh kofisien korelasi parsial antara kepemimpinan dengan efektivitas kerja pegawai sebesar 0,382 dan kofisien korelasi parsial antara kemampuan berkomunikasi guru dengan motivasi belajar siswa sebesar 0,419.

Untuk pengujian hipotesis dengan perhitungan analisis regresi ganda diperoleh Fhitung untuk variabel kepemimpinan adalah 1,824 dan variabel komunikasi intern adalah 1,131 dengan harga Ftabel adalah 2,85. Karena harga Fhitung lebih kecil dari harga Ftabel, menunjukkan bahwa nilai Fhitung yang diperoleh tersebut signifikan. Dengan demikian menunjukkan bahwa ada pengaruh positif kepemimpinan dan komunikasi intern terhadap efektivitas kerja pegawai di Fakultas Ilmu Tarbiyah dan Keguruan UIN Raden Fatah Palembang secara simultan. Dari hasil pengujian tersebut dimana menunjukkan bahwa Fhitung signifikan, maka dapat diartikan bahwa pengaruh kepemimpinan dan komunikasi intern terhadap efektivitas kerja pegawai adalah signifikan.

Besarnya pengaruh kepemimpinan dan komunikasi intern terhadap efektivitas kerja pegawai dapat diketahui dari harga koefisien determinasi simultan (R2). Berdasarkan hasil analisis pada lampiran dan terangkum pada tabel 4.10 diperoleh harga R2 kepemimpinan sebesar 0,134 dan komunikasi intern sebesar 0,363. Dengan demikian menunjukkan bahwa kepemimpinan dan komunikasi intern secara bersama-sama mempengaruhi efektivitas kerja pegawai sebesar 49,7\% dan sisanya yaitu 50,3\% dari efektivitas kerja pegawai dipengaruhi oleh faktor lain yang tidak dikaji dalam penelitian ini. 


\section{PEMBAHASAN}

Efektivitas kerja sangatlah diperlukan dalam suatu organisasi dalam hal ini adalah organisasi kampuas untuk mencapai tujuan yang telah ditetapkan dengan tepat dan capat. Berdasarkan hasil penelitian menunjukkan bahwa ada pengaruh kepemimpinan terhadap efektivitas kerja pegawai secara simultan yang dibuktikan dari hasil uji $\mathrm{F}$ yang memperoleh Fhitung yang memiliki signifikansi kurang dari 0,05. Berdasarkan persamaan regresi yang diperoleh dimana koefisien regresi bertanda positif maka dapat diartikan bahwa terdapat pengaruh yang positif antara kepemimpinan terhadap efektivitas kerja pegawai. Pada proses kerja, seorang pegawai akan mencapai efektivitas kerja bila didukung oleh kepemimpinan yang tepat, sebab efektivitas kerja adalah suatu keadaan dimana aktifitas jasmaniah dan rohaniah yang dilakukan oleh manusia dapat mencapai hasil akibat sesuai yang dikehendaki (Sutarto, 1978:95), kalu seseorang melakukan sesuatu yang memang dikehendakinya maka seseorang itu dikatakan efektif jika menimbulkan akibat atau mempunyai maksud sebagaimana dikehendakinya (Gie, 1998). Efektivitas kerja pegawai dalam bekerja ditentukan oleh dua faktor yaitu faktor intrinsik yang ada pada diri pegawai itu sendiri maupun faktor ekstrinsik yang berada di luar diri pegawai.

Hasil penelitian menunjukkan kepemimpinan berpengaruh terhadap efektivitas kerja pegawai. Hal ini disebabkan dengan kemampuan pemimpin untuk memimpin organisasi secara efektif yang ditunjukkan dari kemampuannya dalam mengarahkan, mempengaruhi, mendidik dan menggerakkan pegawai akan mampu mendorong pegawai dalam bekerja secara efektif. Dimana seseorang yang memiliki kepemimpinan yang baik akan mampu mempengaruhi, membimbing dan mengarahkan atau mengelola orang lain agar mereka mau berbuat demi tercapainya tujuan bersama (Burhanuddin, 1994:2). Kurangnya peranan kepemimpinan dalam sebuah organisasi mengakibatkan kurang optimalnya kerja yang diselesaikan oleh para bawahannya baik menyangkut waktu dan hasil yang dicapainya. Dimana efektivitas bawahan sebagaian besar ditentukan oleh efektivitas kepemimpinan seorang pemimpin (Hasibuan, 2001:42). Salah satu contoh bawahan kurang terarah dalam mengerjakan tugas dan hal tersebut mengakibatkan efektivitas kerja menjadi terhambat.

Secara umum dari keempat indikator kepemimpinan telah baik, akan tetapi ditinjau dari bobot persentase ketercapainyan belum mencapai angka yang ideal, demikian kemampuan pimpinan dalam Telling (memberitahu/intruksi), Selling (mempromosikan), Delegating (mendelegasikan) dan Participating (partisipasi/ peran serta) masih perlu ditingkatkan agar kepemimpinannya di dalam lembaga menjadi lebih baik disamping meningkatkan kemampuan dalam bekerja maupun bekerjasama dengan pegawai dan kemampuan dalam menganalisa dan memecahkan.

Sedangkan komuniksi sebagai salah satu bentuk interaksi antara sesama manusia sangat dibutuhkan dalam bekerja yaitu antara pimpinan dengan pegawai, pimpinan dengan pimpinan, dan sesama pegawai. Sebagaimana makna dari komunikasi intern yaitu komunikasi yang dikirimkan kepada anggota organisasi dalam suatu organisasi (Muhammad, 2001:97), sehingga pegawai akan lebih efektif dalam bekerja.

Berdasarkan uji pengaruh antara komunikasi intern terhadap efektivitas kerja pegawai terbukti bahwa ada pengaruh yang signifikan antara komunikasi intern terhadap efektivitas kerja pegawai, maka berdasarkan persamaan regresi yang diperoleh dimana koefisien regresi bertanda positif maka dapat diartikan bahwa terdapat 
pengaruh yang positif antara komunikasi intern terhadap efektivitas kerja pegawai. Bentuk pengaruh yang diperoleh dari persamaan tersebut yaitu pengaruh positif yang artinya jika variabel komunikasi intern ditingkatkan maka akan diikuti dengan meningkatnya semangat kerja pegawai dan sebaliknya jika komunikasi intern turun maka akan diikuti dengan menurunnya semangat kerja pegawai.

Komunikasi merupakan sarana yang diperlukan untuk mengkoordinasikan dan mengarahkan kegiatan bawahan ketujuan dan sasaran organisasi. Selain itu komunikasi juga sebagai sarana untuk menyatukan arah dan pandangan serta pikiran antara pimpinan dan bawahan. Dengan adanya komunikasi bawahan dapat memperoleh informasi dan petunjuk yang jelas sehingga tidak menimbulkan keragu-raguan dan kesalahpahaman yang pada akhirnya akan mempengaruhi efektivitas kerja pegawai. Dimana yang harus diperhatikan oleh semua personel yang ada dalam suatu organisasi adalah terbinanya komunikasi intern yang baik (Suprihatin, 2004:100). Komunikasi antara pimpinan dengan pegawai ataupun sesama pegawai harus dibina. Pimpinan tidak hanya bertindak sebagai pemberi perintah ataupun pemberi tugas tetapi pimpinan juga harus mampu menampung semua ide, saran dan masukan dari bawahan sehingga antara pimpinan dengan bawahan tidak terjadi kesenjangan. Komunikasi antar pegawai perlu dibina supaya terjadi kesatuan ide yang dapat memperlancar pelaksanaan tugas dan pekerjaan.

Adanya komunikasi intern yang baik akan memudahkan pegawai dalam melaksanakan tugasnya, sehingga terwujud efektivitas kerja pegawai. Adanya komunikasi yang baik secara vertikal maupun horizontal pada lembaga akan memungkinkan semua pesan tugas dari atasan kepada bawahan yang lebih jelas akan memberikan kemudahan bawahan dalam melaksanakan tugas. Sedangkan adanya komunikasi antara pelaksana di tingkat bawah yang baik, akan memungkinkan pertukaran informasi diantara mereka yang akan membantu memperlancar jalannya pelaksanaan tugas tersebut. Dimana komunikasi merupakan sarana yang diperlukan guna untuk mengkoordinasikan dan mengarahkan kegiatan pegawai ketujuan dan sasaran organisasi (Mulyana, 2001:167). Komunikasi juga sebagai sarana menyatukan arah, pandangan serta pikiran antara pimpinan dan bawahan yang pada akhirnya akan memperlancar pelaksanaan tugas. Dengan adanya komunikasi, bawahan dapat memperoleh informasi dan petunjuk yang jelas sehingga tidak menimbulkan keraguraguan dan kesalah pahaman, sehingga akhirnya akan mempengaruhi efektivitas kerja bawahanya. Komunikasi yang baik akan membentuk hubungan antara pegawai dengan pimpinan dan antara sesama pegawai dapat menjadi baik dan harmonis. Ini akan membawa dampak positif antara lain terciptanya rasa memiliki, tanggung jawab, sehingga dapat menumbuhkan partisipasi dan lain sebagainya.

\section{E. KESIMPULAN}

Berdasarkan hasil analisis dan pembahasan di atas dapat disimpulkan bahwa: 1) ada pengaruh yang positif antara kepemimpinan dan komunikasi intern terhadap efektivitas kerja pegawai di Fakultas Ilmu Tarbiyah dan Keguruan UIN Raden Fatah Palembang. 2) besarnya pengaruh masing-masing variabel bebas secara parsial yaitu $13,4 \%$ untuk variabel kepemimpinan dan 36,3\% untuk variabel komunikasi intern. Sedangkan secara simultan besarnya pengaruh kepemimpinan dan komunikasi intern terhadap efektivitas kerja adalah sebesar $49,7 \%$. 


\section{REFERENSI}

Amsyah, Z. (2008). Manajemen Sistem Informasi. Jakarta: Gramedia Pustaka Utama.

Andri, S., \& Sonang, S. (2013). Pengaruh Motivasi, Lingkungan Kerja Dan Komunikasi Intern

Terhadap Kinerja Karyawan Ud. Rezeki Surabaya. Jurnal Ilmu \& Riset Manajemen, Vol.

2 No. 11.

Arifin, A. (1994). Strategi Komunikasi: Sebuah Pengantar Ringkas. Bandung: Armico.

Asmara, H. (1985). Pengantar Kepemimpinan Pendidikan. Jakarta: Ghalia.

Bastian, I. (2010). Akuntansi Sektor Publik Suatu Pengantar Edisi Ketiga. Jakarta: Erlangga.

Burhanuddin. (1994). Analisis Administrasi Manajemen dan Kepemimpinan Pendidikan. Jakarta: Bumi Aksara.

Cangara, H. (2005). Pengantar Ilmu Komunikasi. Jakarta: Rajawali Pres.

Dhamayanti, I. (2007). Efektivitas Komunikasi Internal Antara Pimpinan Dengan Karyawan PT Pidi Visual Project. Prodi Hubungan Masyarakat Fakultas Ilmu Komunikasi Universitas Mercubuana, digilib.mercubuana.ac.id.

Effendy, O. U. (2001). Ilmu Komunikasi: Teori dan Praktek. Bandung: Remaja Rosdakarya. Effendy, O. U. (2003). Ilmu komunikasi; Teori dan Praktek. Bandung: Rosda.

Gie, T. L. (1998). Ensiklopedia Administrasi. Jakarta: Gunung Agung.

Handayaningrat, S. (1996). Pengantar Studi Ilmu Administrasi dan Manajemen. Jakarta: PT.

Toko Gunung Agung.

Handoko, H. T. (1995). Manajemen. Jakarta: BEP Yogyakarta.

Hasibuan, M. S. (2001). Manajemen Sumber Daya Manusia. Jakarta: PT. Bumi Aksara.

Husnan, H. \&. (2002). Manajemen Personalia. Yogyakarta: Bpfe.

Kartono, K. (2008). Pemimpin dan kepemimpinan. Jakarta: Raja Grafindo Persada.

Muhammad, A. (2001). Komunikasi Organisasi. Jakarta. Jakarta: Bumi Aksara.

Muhyadi. (1989). Organisasi Teori Struktur dan Proses. Jakarta: Depdikbud.

Mulyana, D. (2001). Ilmu Komunikasi, Suatu Pengantar. Bandung: Remaja Rosdakarya.

Mulyaningtyas, B. R. (2006). Bimbingan dan Konseling SMA I untuk Kelas X. Jakarta: Penerbit Erlangga.

Novi, S., \& Rachmiyati. (2016). Pengaruh Gaya Kepemimpinan, Komunikasi, dan Motivasi Kerja Terhadap Kerja PNS Pada Polikteknik Negeri Banjarmasi. Jurnal INTEKNA, Vol 16, No. 2. Akses di http://ejurnal.poliban.ac.id/index.php/intekna.

Pasolong, H. (2007). Teori Administrasi Publik. Bandung: Alfabeta.

Purwanto, D. (2006). Komunikasi Bisnis, Edisi Ketiga. Jakarta: Erlangga.

Robbins, S. P. (2002). Prinsip-Prinsip Perilaku Organisasi. Edisi Kelima. (Terjemahan). Jakarta: Erlangga.

Robins, S. P. (1996). Teori Organisasi, Struktur, Desain dan Aplikasi. Jakarta: Arcan. Siagian, S. (2007). Manajemen Sumber Daya Manusia. Jakarta: PT. Bumi Aksara.

Steers, R. M. (1985). Efektifitas Organisasi. Jakarta: Erlangga.

Suprihatin. (2004). Manajemen Sekolah. IKIP Semarang: Badan Penerbit Universitas Diponogoro.

Susanto, A. (2008). Sistem Informasi Manajemen. Bandung: Lingga Jaya.

Sutarto. (1991). Dasar-Dasar Komunikasi Administrasi 1. Yogyakarta: Data Wacana University Press.

Sutarto. (1978). Dasar-dasar Organisasi. Yogyakarta: Gajah Mada University Press.

Suyuti, A. (2001). Pelatihan Dasar Kepemimpinan (Leadership) dari Aspek Etik dan Moral. Pekalongan: Cinta Ilmu.

Usman, H. (2013). Manajemen (Teori, Praktek, dan Riset Pendidikan). Jakarta: Bumi Aksara.

Widjaja, H. (2000). Ilmu Komunikasi Pengantar Studi. Jakarta: Rineka Cipta. 